
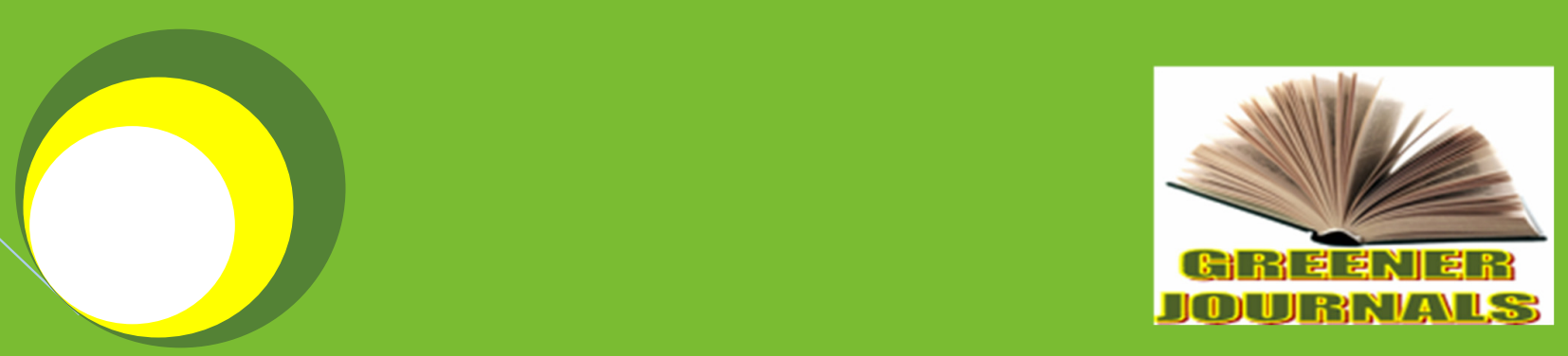

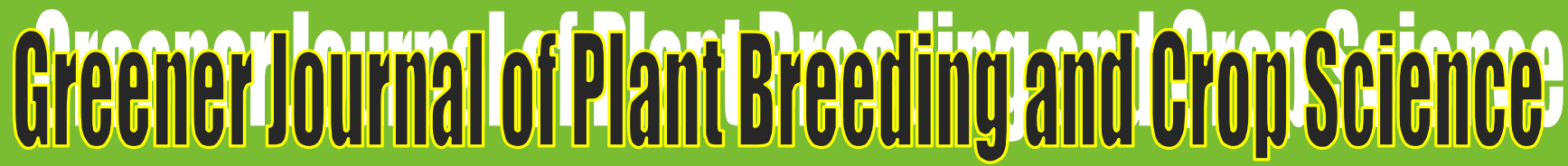

ISSN: 2354-2292

Submitted: 25/08/2016

Accepted: 20/09/2016

Published: 08/11/2016

DOI: http://doi.org/10.15580/GJPBCS.2016.5.082516139

The Effect of Different

Growth Stages on

Some Forage Quality

Characters of the Leaf

and Stem in Four

Newly Developed

Genotypes of Blue

Melilot (Melilotus

coeruleus (L.) Desr.)

By

Ertan Ates 


\title{
The Effect of Different Growth Stages on Some Forage Quality Characters of the Leaf and Stem in Four Newly Developed Genotypes of Blue Melilot (Melilotus caeruleus (L.) Desr.)
}

\author{
Ertan Ates
}

\author{
Department of Field Crops, Faculty of Agriculture, University of Namik Kemal, Tekirdag, Turkey \\ Email: ertan_ates@ hotmail.com
}

\begin{abstract}
This research was carried out in 2012-2014 on clay soil with pH 6.9 on the farm land of Malkara-Tekirdag in Turkey located at $40.0{ }^{\circ} \mathrm{N}, 26 .{ }^{\circ} \mathrm{E}$, about $254 \mathrm{~m}$ altitude sea level, with a typical subtropical climate. The aim of this study was to determine some forage quality characteristics of stems and leaves in four newly developed genotypes of blue melilot at different growth stages. Four blue melilot genotypes (BG-1, BG-2, BG-3 and BG-4) were evaluated with mass selection. Higher leaf fresh yield $\left(9.38 \mathrm{t} \mathrm{ha}^{-1}\right)$ and leaf dry matter yield $\left(3.44 \mathrm{t} \mathrm{ha}^{-1}\right)$ were found in the BG-3 genotype, whereas its exhibited lower values than other genotypes for the stem fresh matter yield $\left(0.80 \mathrm{tha}^{-1}\right)$ and dry matter yield $\left(0.31 \mathrm{t} \mathrm{ha}^{-1}\right)$ at pre-bud growth stage. The CP, ADF, NDF, ADL, $\mathrm{Ca}, \mathrm{Mg}, \mathrm{K}$ and $\mathrm{P}$ contents in the leaves and stems of blue melilot genotypes were adequate for ruminant and non ruminant animals. NDF, ADF and ADL contents increase with the progress of blue melilot development both in the stem and leaf. The leaves are more abundantly supplied with minerals then the stem. The $\mathrm{CP}, \mathrm{Ca}$ and $\mathbf{P}$ contents and fresh and dry matter yields of leaves in candidate genotype BG-3 blue melilot line was determined to be higher than other genotypes.
\end{abstract}

Key words: blue melilot, forage quality, genotype, mineral content, Melilotus caeruleus (L.) Desr.

\section{INTRODUCTION}

Forage crops are the natural feeds of all herbivores and omnivores, including ruminant and non-ruminant. Some forage crops are generally included in all balanced rations for herbivores- even in high- concentrate rations. Nonruminant animals can utilize forage crops reasonably well, although not as efficiently as ruminants. For forage crops to be of superior quality, it must be high in four factors: (a) nutrients, (b) digestibility, (c) palatability, and (d) efficiency of utilization (Ensminger et al., 1990). Generally, forage legumes are more digestible and passes through the digestive tract more rapidly than low-quality other forage crops; hence, herbivores will consume more of it. However, growing stages of forage crops and leaf/stem ratio affects yield, palatability, digestibility and chemical composition (protein, mineral contents, vitamins). For example, mature forage legumes are high in fiber content and low in protein, $\beta$-carotene and $\alpha$-tocopherol contents.

Blue melilot is an herbaceous annual legume. It originated in west Anatolia and Mediterranean region in areas that surround Caucasian. Blue melilot is adapted to a wide range of soil types, but it is best-suited in lowlying areas, with well-drained, chernozem, vertisol and airy textured soils of pH from 6 to 8 . It has been successfully grown in areas that receive 450 to $1200 \mathrm{~mm}$ annual rainfall. The leaves are trifoliate, alternate, with stipules adnate to the leaf-stalk, and heads or dense spikes of small blue, purple or white flowers; the small, one seeded roundish pods are enclosed in the calyx. The seeds are usually dark goldenrod or ochre in color (Ates, 2015). Blue melilot is used as forage, soil improvement, aromatic (alpha keto acids), medical [á-ketoisocaproic acid $\left(\mathrm{C}_{6} \mathrm{H}_{10} \mathrm{O}_{3}\right)$, pyruvic acid $\left(\mathrm{C}_{3} \mathrm{H}_{4} \mathrm{O}_{3}\right)$, á-ketoisovaleric acid $\left(\mathrm{C}_{5} \mathrm{H}_{8} \mathrm{O}_{3}\right)$ and á-ketoglutaric acid $\left.\left(\mathrm{C}_{5} \mathrm{H}_{6} \mathrm{O}_{5}\right)\right]$ and culinary plants (Ates, 2011). Nevertheless; in Thrace region of Turkey, Balkan countries and Georgia, the dried plants and seeds of blue melilot are widely utilized as a spice, usually sold as a playe greenish-brown powder consisting of leaves, pods and seeds. (Ates, 2015).

The aim of this study was to determine some forage quality characteristics of stems and leaves in four newly developed genotypes of blue melilot (Melilotus caeruleus (L.) Desr.) at different growth stages. 


\section{MATERIALS AND METHODS}

This study was carried out in 2012-2014 on clay soil with pH 6.9 on the farm land of Malkara-Tekirdag in Turkey located at $40.0{ }^{\circ} \mathrm{N}, 26.0^{\circ} \mathrm{E}$, about $254 \mathrm{~m}$ altitude sea level, with a typical subtropical climate. The soil of the experimental area was low in organic matter (1.29\%), moderate in phosphorus content $\left(61.1 \mathrm{~kg} \mathrm{ha}^{-1}\right)$, but rich in potassium content $\left(521.9 \mathrm{~kg} \mathrm{ha}^{-1}\right)$. The total rainfall of experimental area was $700 \mathrm{~mm}$. This location has approximately similar overall temperature $\left(12.9{ }^{\circ} \mathrm{C}\right)$ during vegetation period. At each year, a basal fertilizer containing $\mathrm{N}$ and $\mathrm{P}\left(45 \mathrm{~kg} \mathrm{ha}^{-1}\right)$ was incorporated into the soil at the time of land preparation.

Four blue melilot genotypes (BG-1, BG-2, BG-3 and BG-4) were evaluated with mass selection and one population as control were planted in two-factor factorial randomized block design with three replications. Blue melilot population seeds were collected during 2005-2006 at mature stage from grasslands $\left(43.0^{\circ} \mathrm{N}, 26.0^{\circ} \mathrm{E}\right)$ of the Belovets village in Razgrad, the north-east of Bulgaria. These seeds are renewed annually. Each genotype was sown in plots of 8 rows, with a spacing of $20 \mathrm{~cm}$ and $5 \mathrm{~m}$ in length. The seeds were sown at a rate of $20 \mathrm{~kg}$ $\mathrm{ha}^{-1}$ on November $12^{\text {th }}, 2012$ and October $30^{\text {th }}, 2013$. The plots were not irrigated after they were sown and harvested. One cut was made in each year at the three growing stages such as pre-bud, $1 / 2$ bloom and full-bloom. The central one square meter sections were cut at ground level at the three growing stages for dry matter contents of stem and leaf. Samples were hand-separated into leaf (including leaf sheath and inflorescence) and stem components. Then, stem and leaf fresh matter (FM) yield $\left(t \mathrm{ha}^{-1}\right)$ for each genotypes were determined and recorded (Kok et al., 2007). The dry matter (DM) yield $\left(\mathrm{t} \mathrm{ha}^{-1}\right)$ for those samples were calculated by drying approximately $100 \mathrm{~g}$ samples at $55^{\circ} \mathrm{C}$ for $24 \mathrm{~h}$ followed by storage for a further day at room temperature (Tekeli and Ates, 2006).

Dried plant parts were ground to small $(\leq 1 \mathrm{~mm})$ pieces and used for the analyses. Stem and leaf samples were analysed for nitrogen $(\mathrm{N})$ using procedures of the Association of Official Analytical Chemists (AOAC, 2007). Crude protein (CP) contents (\%) of the samples were calculated by multiplying $N$ contents by a coefficient of 6.25. The neutral detergent fibre (NDF), acid detergent fibre (ADF) and acid detergent lignin (ADL) contents were determined according to the methods described by Van Soest et al. (1991). The samples were wet-fired with nitric-perchloric acid, and phosphorus (P) content was determined spectrophotometrically. Potassium (K), calcium (Ca) and magnesium ( $\mathrm{Mg}$ ) contents were found using an atomic absorption spectrophotometer. All leaf and stem samples were analyzed in triplicate. Analysis of variance was performed on all data (means of two years, after arcsine transformation of root square of percentage values) using TARIST program.

\section{RESULTS AND DISCUSSION}

Some forage quality characters, fresh and dry matter yields of leaves and stems for the blue melilot genotypes are given in Tables 1 and 2 . The enormous changeability in the relative amounts of the nutritive compounds and yield of the forage crops arises for the most part from variations in growth rate due to soil and other ecological conditions and differences in stage of maturity. However, more than 65 chemical elements are found in forage legumes. The major amount of protein and minerals in forage legumes occurs in the leaves. Morphological definitions of quality emphasize leaf yield or leaf/stem ratio. Besides, these traits are used as an indicator of digestibility and intake in forage. Higher leaf FM yield $\left(9.38 \mathrm{t} \mathrm{ha}^{-1}\right)$ and DM yield (3.44t ha-1) were found in the BG-3 genotype, whereas its exhibited lower values $(P<0.01)$ than other genotypes for the stem FM yield $(0.80 t$ $\mathrm{ha}^{-1}$ ) and DM yield $\left(0.31 \mathrm{t} \mathrm{ha}^{-1}\right)$ at pre-bud growth stage (Table 1 and 2). Besides, FM and DM yields of stem and leaf were affected significantly $(P<0.01)$ by growth stages. Higher yields were obtained at full-bloom stage compared to at other growth stages (Table 1 and 2). Meyer (2005) determined that forage yields of yellow melilot (M. officinalis (L.) Pall.) at pre-bud, $10 \%$ bloom and late-bloom stages ranging from $7.18 \mathrm{t} \mathrm{ha}^{-1}, 7.43 \mathrm{t} \mathrm{ha}^{-1}$ and $5.20 \mathrm{t} \mathrm{ha}^{-1}$, respectively, whereas Ates (2015) emphasized this value to be only 2.98-3.11 $\mathrm{t} \mathrm{ha}^{-1}$ for blue melilot. Luo et al. (2016) studied the genotypic variation in a breeding population of yellow melilot, they found a leaf/stem ratio of $0.93-0.96$ for this plant.

A significant genotype and genotype $\mathrm{x}$ growth stage interactions were found for $\mathrm{CP}$ ratios of stem and leaf. The effect of growth stages on CP ratio of leaves were found to be not significant $(P>0.05,0.01)$. Lower stem CP ratio $(12.87 \%)$ and leaf CP ratio $(22.88 \%)$ were determined for population at full-bloom stage (Table 1 and 2). The CP content and fractionation varied depending on the forage crop species or varieties (Ates, 2012). Hubbard (2016) stated that forage legumes insure good protein for ruminants. High-producing dairy cows need hay with at least $20 \% \mathrm{CP}$. When CP is less than 35\%, much of the forage passes through the rumen without being absorbed, so it is essentially wasted (Redfearn et al., 2008). The leaves have stable protein content and their protein level is much higher than the protein content in stems (Milić et al., 2011). As plant growth advances, there is a greater accumulation of lignin and cellulose in the stem, while the content of CP decreases (Ocokoljić, 1975). The decrease in CP contents in the leaf with plant aging is closely related to an increase in the proportion of old leaves in later growth stages and translocation of nutrients from leaf to generative organs and root (Marković et al., 2007). The decline of digestibility is the consequence of two processes: (i) the reduction of the highly digestible components in leaves because of an increase of the less digestible component in stem and (ii) the decreasing average digestibility of the stem component, with more NDF and lignin (Veronesi et al., 2010; 
Milić et al., 2011). Kostopoulou et al. (2015) reported that stem CP ratio and leaf CP ratio ranging from 12.6$12.8 \%$ and $20.8-22.3 \%$, respectively. Similar findings have been for alfalfa (Medicago sativa L.) and annual yellow melilot (M. indica (L.) Allioni) (Bhatta et al., 2002; Marković et al., 2007; Milić et al., 2011). The results were similar to those reported by these researchers.

The results presented here have shown that NDF, ADF and ADL ratios increases with the progress of crop development both in leaves and stems ( $P<0.01$; Table 1 and 2$)$. The minimum NDF $(47.70 \%$ in stem; 16.90 $\%$ in leaf), ADF (36.98 \% in stem; $9.41 \%$ in leaf) and ADL (4.10\% in stem; $1.60 \%$ in leaf) ratios were determined for BG-3 blue melilot genotype at pre-bud stage. NDF is the more complete measure of total fiber since it measures all the cellulose, lignin and hemicellulose. Crude fiber measures only cellulose and some lignin whereas ADF includes cellulose and all the lignin. For this reason, ADF appears to be more closely associated with digestibility and NDF with rumen fill or dry matter intake. Dry matter intake and milk production are highly correlated so any component of the ration affecting dry matter intake would affect milk production (Harris, Jr., 1997). Forage legumes are lower in NDF, ADF and ADL at a given stage of growth than forage grasses. High quality forage legumes hay will contain 30 to $40 \%$ NDF and 20 to $30 \%$ ADF. Minson (1990) reported that the ratio of cell walls in leaves increased with plant ager only up to $10 \%$, so that declining quality of fiber feeds is closely related with a decreasing proportion of leaves in total plant biomass and reduced quality of stems. Quality of legumes and grasses is best estimated by their potential DMI and dry matter digestibility (DDM) which are determined by the NDF and ADF fractions, respectively. Both NDF and ADF increase as the plant matures causing a decline in the quality of the forage (Linn and Kuehn, 1997). Guerrero-Rodríguez (2006) investigated growth and nutritive value of alfalfa and white melilot ( $M$. albus medik.) under saline conditions and obtained similar values for NDF (47.6-55.6 \% in stem; 16.8-27.0\% in leaf), ADF (39.7-42.2 \% in stem; $9.1-12.1 \%$ in leaf) and ADL (5.2-5.5\% in stem; 1.6-2.5\% in leaf). Marković et al. (2007) found the highest amounts of NDF (867.1 g $\left.\mathrm{kg}^{-1}\right)$ and ADF (499.4 $\left.\mathrm{g} \mathrm{kg}^{-1}\right)$ in the stem base of alfalfa at full-bloom stage. Yisehak (2008) emphasized that the NDF and ADF ratios ranged from 37.2 and $33.2 \%$, respectively in white melilot. The results were similar to those reported by these researchers.

The effect of genotype, growth stage and genotype $\mathrm{x}$ growth stage interaction on $\mathrm{Ca}$ and $\mathrm{K}$ contents of stems were found to be not significant $(P>0.05,0.01)$, whereas $C a$ content of leaves was influenced significantly by genotype, growth stage and interaction effect of genotype $x$ growth stage (Table 2). In addition to a significant genotypic effect was significant for $\mathrm{K}$ content of leaves $(\mathrm{P}<0.01)$. The $\mathrm{Ca}$ and $\mathrm{K}$ contents of stems were ranged from 7.77 to $8.47 \mathrm{~g} \mathrm{~kg}-1$ and 29.86 to $31.55 \mathrm{~g} \mathrm{~kg}-1$, respectively. The lowest Ca content of leaves were found in population (17.77-18.02 g kg-1), BG-2 (17.87 g kg-1) and BG-1 (18.0 g kg-1) genotypes at pre-bud and 50\% bloom stages. Lower leaf $\mathrm{K}$ content $(14.66 \mathrm{~g} \mathrm{~kg}-1)$ was obtained for all genotypes at pre-bud stage. BG-3 blue melilot genotype exhibited higher values than other genotypes for the P content of stem $(1.82 \mathrm{~g} \mathrm{~kg}-1)$ and leaf (4.83 $\mathrm{g} \mathrm{kg}$-1) (Table 1 and 2). A significant genotype, growth stages and genotype $\mathrm{x}$ growth stage interaction were found for $\mathrm{Mg}$ content of stems and leaves $(P<0.01)$. The lowest $\mathrm{Mg}$ contents of stems and leaves were recorded in pre-bud stage of development. Highest Mg contents of stems (1.89-1.91 g kg-1) and leaves $(4.85 \mathrm{~g}$ $\mathrm{kg}-1$ ) were determined in genotypes BG-3, BG-4 and BG-4, population, respectively (Table 1 and 2). The mineral elements are contained in approximately $1.5-5 \%$ of the animal body (Tekeli et al. 2003) and their balances are very important to keep animal health. A lack of one mineral element cannot be balanced by the others. These elements could have certain ratio. For example, $\mathrm{Ca}$ and $\mathrm{P}$ are closely related to animal health and metabolism. It is very important to keep a proper balance of $\mathrm{Ca}$ and $\mathrm{P}$ in relation to vitamin $\mathrm{D}$ (Ates and Tekeli, 2005). Although $\mathrm{Ca}, \mathrm{K}, \mathrm{Mg}$ and all micro minerals contents in the stems were lower, their levels in the leaves and stems of yellow melilot were adequate for sheep (Ovis aries L.). (NRC, 2007). Effects of $\mathrm{NaCl}$ salinity and plant age on allocation of biomass and mineral elements in kumoniga ( $M$. segetalis (Brot.) Ser.) were studied by Romero and Marañón (1996), who reported immobile $\mathrm{Ca}$ accumulated in leaves with age, whereas $\mathrm{K}$ was depleted from roots and accumulated in leaves and fruits. They found a K relative content of $2.29 \%$, a Ca relative content of $5.14 \%$ and a $\mathrm{P}$ relative content of $0.24 \%$ for kumoniga. Gizachew and Smit (2005), who investigated the CP and mineral composition of major crop residues and supplemental feeds, reported contents of $16.0 \mathrm{~g} \mathrm{~kg}-1$ for $\mathrm{Ca}$ and $19.9 \mathrm{~g}$ $\mathrm{kg}-1$ for $\mathrm{K}$ in grass pea (Lathyrus sativus L.) haulms. Kostopoulou et al. (2015) reported the content of K, Ca and $\mathrm{Mg}$ in the leaves ranged from 14.61 to $23.53 \mathrm{~g} \mathrm{~kg}-1,17.55$ to $18.32 \mathrm{~g} \mathrm{~kg}-1$ and 4.50 to $4.96 \mathrm{~g} \mathrm{~kg}-1$ respectively in yellow melilot. 
Table 1: Some forage quality characteristics, fresh and dry matter yields of stems in blue melilot genotypes at different growth stages (means of two years)

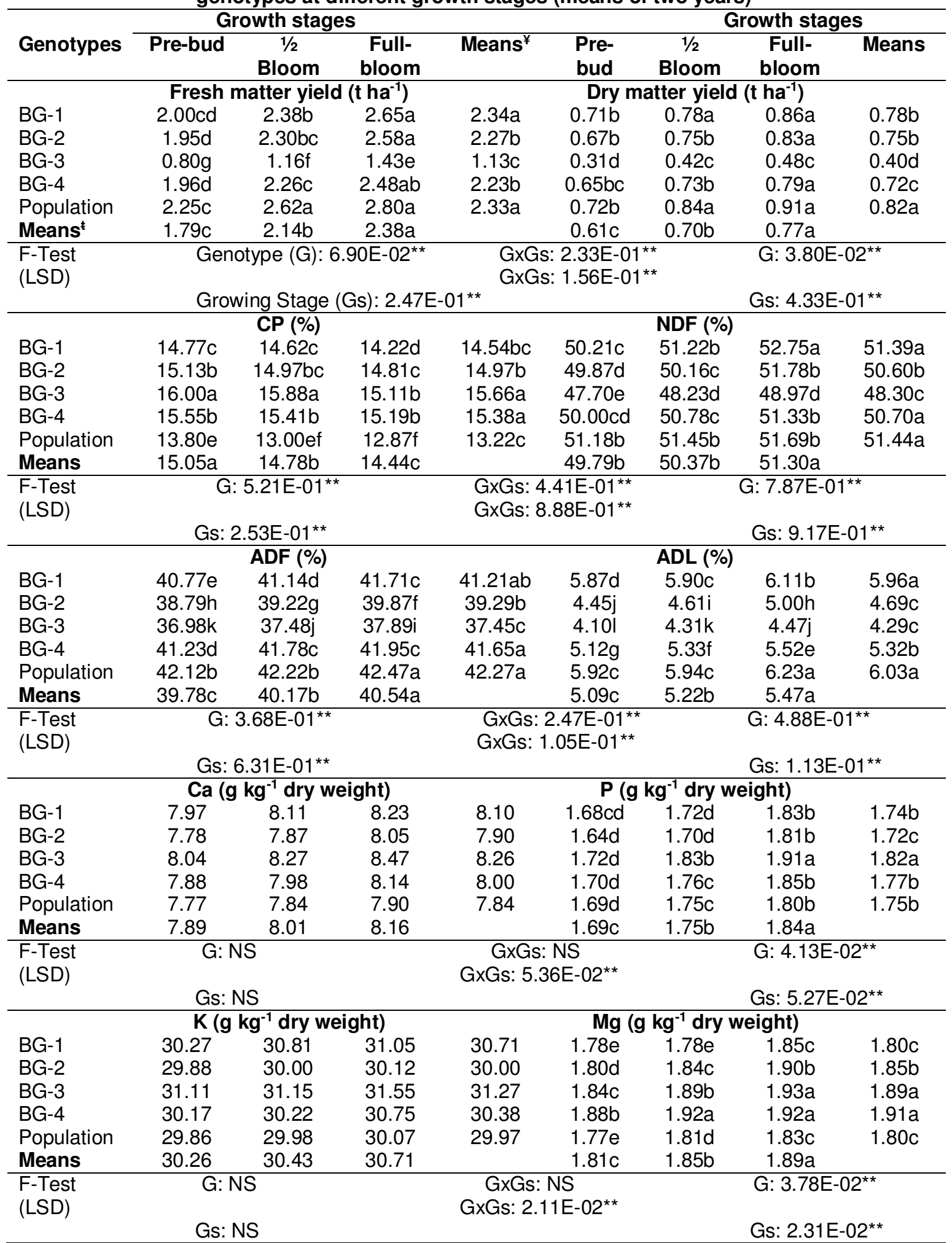

${ }^{* *}: p<0.01$, NS: $p>0.01$, ${ }^{\ddagger}$ Genotype means and genotype $\times$ growth stage interactions with different letter for the same column are significantly different $(p<0.01)$; *Growth stage means with different letter for the same row are significantly different $(p<0.01)$ 
Table 2: Some forage quality characteristics, fresh and dry matter yields of leaves in blue melilot genotypes at different growth stages (means of two years)

\begin{tabular}{|c|c|c|c|c|c|c|c|c|}
\hline \multirow[b]{2}{*}{ Genotypes } & \multicolumn{4}{|c|}{ Growth stages } & \multicolumn{4}{|c|}{ Growth stages } \\
\hline & Pre-bud & $\begin{array}{c}1 / 2 \\
\text { Bloom }\end{array}$ & $\begin{array}{c}\text { Full- } \\
\text { bloom }\end{array}$ & Means $^{*}$ & $\begin{array}{l}\text { Pre- } \\
\text { bud }\end{array}$ & Bloom & $\begin{array}{c}\text { Full- } \\
\text { bloom }\end{array}$ & Means \\
\hline & \multicolumn{3}{|c|}{ Fresh matter yield $\left(\mathrm{t} \mathrm{ha}^{-1}\right)$} & \multicolumn{5}{|c|}{ Dry matter yield $\left(\mathrm{t} \mathrm{ha}^{-1}\right)$} \\
\hline BG-1 & $6.00 \mathrm{~h}$ & $6.40 \mathrm{~g}$ & $6.50 \mathrm{~g}$ & $6.30 \mathrm{c}$ & $1.55 \mathrm{~h}$ & $1.58 \mathrm{~h}$ & $1.62 \mathrm{~h}$ & $1.58 \mathrm{~d}$ \\
\hline BG-2 & $7.80 \mathrm{~d}$ & $7.95 \mathrm{~d}$ & $8.17 \mathrm{c}$ & $7.97 \mathrm{~b}$ & $2.01 \mathrm{e}$ & $2.11 \mathrm{e}$ & $2.41 d$ & $2.18 \mathrm{~b}$ \\
\hline BG-3 & $9.18 \mathrm{~b}$ & $9.38 \mathrm{a}$ & $9.57 a$ & $9.38 \mathrm{a}$ & $3.21 \mathrm{c}$ & $3.43 \mathrm{~b}$ & $3.69 a$ & $3.44 a$ \\
\hline BG-4 & $6.56 \mathrm{fg}$ & $6.76 f$ & $7.05 \mathrm{e}$ & $6.79 \mathrm{c}$ & $1.70 \mathrm{~g}$ & $1.83 f$ & $2.00 \mathrm{e}$ & $1.84 \mathrm{c}$ \\
\hline Population & $5.25 i$ & $5.32 \mathrm{i}$ & $5.20 \mathrm{i}$ & $5.26 \mathrm{~d}$ & $1.23 \mathrm{i}$ & $1.30 \mathrm{i}$ & $1.18 \mathrm{i}$ & $1.24 \mathrm{e}$ \\
\hline Means $^{*}$ & $6.96 \mathrm{c}$ & $7.16 \mathrm{~b}$ & $7.30 \mathrm{a}$ & & $1.94 \mathrm{c}$ & $2.05 \mathrm{~b}$ & $2.18 a$ & \\
\hline \multirow[t]{2}{*}{$\begin{array}{l}\text { F-Test } \\
\text { (LSD) }\end{array}$} & \multicolumn{3}{|c|}{ Genotype (G): 5.00E-01** } & \multirow{2}{*}{\multicolumn{2}{|c|}{$\begin{array}{l}\text { GxGs: } 1.97 \mathrm{E}-01 \\
\text { GxGs: } 2.16 \mathrm{E}-01^{* *}\end{array}$}} & \multicolumn{3}{|c|}{ G: $3.19 \mathrm{E}-01^{\star *}$} \\
\hline & \multicolumn{3}{|c|}{ Growing Stage (Gs): $1.22 \mathrm{E}-01^{* *}$} & & & \multicolumn{3}{|c|}{ Gs: $1.06 \mathrm{E}-01^{* *}$} \\
\hline & \multicolumn{3}{|c|}{ CP (\%) } & & & \multicolumn{3}{|c|}{ NDF (\%) } \\
\hline BG-1 & $24.71 \mathrm{e}$ & $24.33 f$ & $24.10 \mathrm{~g}$ & $24.38 \mathrm{c}$ & $18.56 \mathrm{j}$ & $18.89 \mathrm{i}$ & $19.15 \mathrm{~h}$ & $18.87 d$ \\
\hline BG-2 & $23.79 \mathrm{~h}$ & 23.70h & $23.12 \mathrm{i}$ & $23.54 d$ & $21.20 \mathrm{~g}$ & $21.71 f$ & $22.13 e$ & $21.68 \mathrm{c}$ \\
\hline BG-3 & $26.21 a$ & $26.05 a$ & $25.94 b$ & $26.07 a$ & $16.90 \mathrm{~m}$ & 17.12 & $17.33 \mathrm{k}$ & $17.12 \mathrm{e}$ \\
\hline BG-4 & $25.45 \mathrm{c}$ & $25.31 \mathrm{c}$ & $25.19 d$ & $25.32 \mathrm{~b}$ & $22.13 \mathrm{e}$ & $22.40 \mathrm{~d}$ & $22.78 \mathrm{c}$ & $22.44 \mathrm{~b}$ \\
\hline Population & $23.22 \mathrm{i}$ & $23.08 \mathrm{i}$ & $22.88 j$ & $23.06 d$ & $25.70 \mathrm{~b}$ & $26.12 a$ & $26.24 a$ & $26.02 a$ \\
\hline Means & 24.68 & 24.49 & 24.25 & & $20.90 \mathrm{~b}$ & $21.25 a$ & $21.53 a$ & \\
\hline \multirow[t]{2}{*}{$\begin{array}{l}\text { F-Test } \\
\text { (LSD) }\end{array}$} & \multicolumn{3}{|c|}{ G: $7.33 \mathrm{E}-01$} & \multirow{2}{*}{\multicolumn{2}{|c|}{$\begin{array}{l}\text { GxGs: } 1.70 \mathrm{E}-01^{\star *} \\
\text { GxGs: } 1.27 \mathrm{E}-01^{\star *}\end{array}$}} & \multicolumn{2}{|c|}{$\mathrm{G}: 7.41 \mathrm{E}-01^{* *}$} & \\
\hline & \multicolumn{3}{|l|}{ Gs: NS } & & & \multicolumn{3}{|c|}{ Gs: $2.81 \mathrm{E}-01^{\star *}$} \\
\hline & \multicolumn{3}{|c|}{ ADF (\%) } & & & \multicolumn{2}{|c|}{ ADL (\%) } & \\
\hline BG-1 & $10.25 \mathrm{k}$ & $10.67 j$ & $10.88 \mathrm{i}$ & $10.60 d$ & $1.89 f$ & $1.95 \mathrm{e}$ & $2.05 d$ & $1.96 \mathrm{~b}$ \\
\hline BG-2 & $11.05 \mathrm{~h}$ & $11.37 f$ & $11.85 d$ & $11.42 \mathrm{c}$ & $1.78 \mathrm{~g}$ & $1.85 f$ & $1.96 \mathrm{e}$ & $1.86 \mathrm{c}$ \\
\hline BG-3 & $9.41 n$ & $9.66 \mathrm{~m}$ & 9.781 & $9.62 \mathrm{e}$ & $1.60 \mathrm{j}$ & $1.67 \mathrm{i}$ & $1.72 \mathrm{~h}$ & $1.66 \mathrm{~d}$ \\
\hline BG-4 & $11.21 \mathrm{~g}$ & $11.56 \mathrm{e}$ & $11.90 d$ & $11.56 \mathrm{~b}$ & $1.74 \mathrm{~h}$ & $1.80 \mathrm{~g}$ & $1.87 f$ & $1.80 \mathrm{c}$ \\
\hline Population & $12.14 \mathrm{c}$ & $12.30 \mathrm{~b}$ & $12.61 \mathrm{a}$ & $12.35 a$ & $2.12 \mathrm{c}$ & $2.31 b$ & $2.47 a$ & $2.30 a$ \\
\hline Means & $10.81 \mathrm{c}$ & $11.11 \mathrm{~b}$ & $11.40 \mathrm{a}$ & & $1.83 \mathrm{c}$ & $1.92 \mathrm{~b}$ & $2.01 a$ & \\
\hline \multirow[t]{3}{*}{$\begin{array}{l}\text { F-Test } \\
\text { (LSD) }\end{array}$} & G: $1.36 \mathrm{E}-0$ & $1^{\star *}$ & & $\begin{array}{l}\text { s: } 1.59 \mathrm{E} \\
\text { s: } 4.70 \mathrm{E}\end{array}$ & & G: 9. & $=-02^{\star *}$ & \\
\hline & Gs: $2.35 \mathrm{E}-$ & $01^{* *}$ & & & & Gs: & $10 \mathrm{E}-02^{\star \star}$ & \\
\hline & $\mathrm{Ca}(\mathrm{g}$ & $\mathrm{kg}^{-1}$ dry v & ight) & & $P(c$ & $\mathrm{gg}^{-1}$ dry $\mathrm{u}$ & ight) & \\
\hline BG-1 & $18.00 \mathrm{c}$ & $18.31 \mathrm{~b}$ & $19.11 a$ & $18.47 a$ & $4.05 d$ & $4.25 \mathrm{c}$ & $4.56 \mathrm{~b}$ & $4.29 b$ \\
\hline BG-2 & $17.87 \mathrm{c}$ & $18.07 \mathrm{~b}$ & $18.25 b$ & $18.06 \mathrm{~b}$ & $4.22 \mathrm{c}$ & $4.37 \mathrm{c}$ & $4.48 \mathrm{~b}$ & $4.36 \mathrm{~b}$ \\
\hline BG-3 & $18.14 b$ & $18.20 \mathrm{~b}$ & $19.00 \mathrm{a}$ & $18.45 a$ & $4.77 a$ & $4.78 \mathrm{a}$ & $4.95 a$ & $4.83 a$ \\
\hline BG-4 & $18.88 \mathrm{a}$ & $19.00 a$ & $19.14 a$ & $19.01 a$ & $4.11 d$ & $4.25 \mathrm{c}$ & $4.30 c$ & $4.22 \mathrm{~b}$ \\
\hline Population & $17.77 \mathrm{c}$ & $18.02 \mathrm{c}$ & $18.13 b$ & $17.97 \mathrm{~b}$ & $4.09 \mathrm{~d}$ & $4.22 \mathrm{c}$ & $4.47 \mathrm{~b}$ & $4.26 \mathrm{~b}$ \\
\hline Means & $18.13 c$ & $18.32 \mathrm{~b}$ & $18.73 a$ & & $4.25 c$ & $4.37 \mathrm{~b}$ & $4.55 a$ & \\
\hline $\begin{array}{l}\text { F-Test } \\
\text { (LSD) }\end{array}$ & G: $5.60 \mathrm{E}-0$ & & & às: $2.62 \mathrm{E}$ & & G: 4. & $\mathrm{E}-01^{* *}$ & \\
\hline & Gs: $1.71 \mathrm{E}$ & $01^{* *}$ & & & & Gs: & $15 \mathrm{E}-01^{* *}$ & \\
\hline & $K(g$ & $\mathrm{kg}^{-1}$ dry w & ght) & & $\mathbf{M g}$ & $\mathbf{k g}^{-1}$ dry & ight) & \\
\hline BG-1 & 14.55 & 15.00 & 15.12 & 14.89 & $4.45 f$ & $4.52 \mathrm{e}$ & $4.54 d$ & $4.50 c$ \\
\hline BG-2 & 14.75 & 15.07 & 15.17 & 15.00 & $4.60 \mathrm{~d}$ & $4.59 d$ & $4.61 d$ & $4.60 \mathrm{~b}$ \\
\hline BG-3 & 14.65 & 14.85 & 15.11 & 14.87 & $4.55 d$ & $4.74 b$ & $4.81 \mathrm{~b}$ & $4.70 \mathrm{~b}$ \\
\hline BG-4 & 14.70 & 14.83 & 15.09 & 14.87 & $4.80 \mathrm{~b}$ & $4.85 a$ & $4.91 \mathrm{a}$ & $4.85 a$ \\
\hline Population & 14.66 & 14.78 & 15.14 & 14.86 & $4.70 \mathrm{c}$ & $4.93 a$ & $4.93 a$ & $4.85 a$ \\
\hline Means & $14.66 \mathrm{~b}$ & $14.91 \mathrm{a}$ & $15.13 a$ & & $4.62 \mathrm{~b}$ & $4.73 a$ & $4.76 a$ & \\
\hline
\end{tabular}

F-Test

G: NS

GxGs: NS

G: $1.48 \mathrm{E}-01^{* *}$

(LSD) GxGs: 8.00E-02**

Gs: $2.21 \mathrm{E}-01^{* *}$

Gs: $1.00 \mathrm{E}-01^{* *}$

${ }^{* *}: p<0.01$, NS: $p>0.01,{ }^{\ddagger}$ Genotype means and genotype $\times$ growth stage interactions with different letter for the same column are significantly different $(p<0.01)$; *Growth stage means with different letter for the same row are significantly different $(p<0.01)$ 


\section{CONCLUSION}

The fresh and dry natter yields and $\mathrm{CP}, \mathrm{ADF}, \mathrm{NDF}, \mathrm{ADL}, \mathrm{Ca}, \mathrm{Mg}, \mathrm{K}$ and $\mathrm{P}$ contents in the leaves and stems of blue melilot genotypes were adequate for ruminant and no ruminant animals. NDF, ADF and ADL contents increase with the progress of blue melilot development both in the stem and leaf. The leaves are more abundantly supplied with minerals then the stem. The CP, Ca and P contents and fresh and dry matter yields of leaves in candidate genotype BG-3 blue melilot line was determined to be higher than other genotypes.

\section{REFERENCES}

AOAC (2007). Official Methods of Analysis. 18th ed., Association of Official Analytical Chemists, Washington, DC, USA.

Ates E (2011). Determination of forage yield and its components in blue melilot (Melilotus caerulea (L.) Desr.) grown in the western region of Turkey. Cuban J. Agric. Sci. 45: 299-302.

Ates E (2012). The mineral, amino acid and fiber contents and forage yield of field pea (Pisum arvense L.), fiddleneck (Phacelia tanacetifolia Benth.) and their mixtures under dry land conditions in the western Turkey. Rom. Agric. Res., 29: 237-244.

Ates E (2015). Performance of four blue melilot (Melilotus caeruleus (L.) Desr.) lines grown at two locations in the Thrace region of Turkey. Range Mgmt. \& Agroforestry 36: 122-127.

Ates E. and Tekeli AS (2005). Forage quality and tetany potential of orchardgrass (Dactylis glomerata L.) and white clover (Trifolium repens L.) mixtures. Cuban J. Agric. Sci. 39: 97-102.

Bhatta R, Shinde AK, Sankhyan SK and Verma DL (2002). Nutrition of range goats in a shrubland of western India. Asian-Aust. J. Anim. Sci. 15: 1719-1724.

Ensminger ME, Oldfield JE and Heinemann WW (1990). Feeds. In: Feeds\&Nutrition. The Ensminger Publishing Company, California, USA. pp: 253-260.

Gizachew L and Smit GN (2005). Crude protein and mineral composition of major crop residues and supplemental feeds produced on Vertisols of the Ethiopian highland. Anim Feed Sci Technol 119, 143-153.

Guerrero-Rodríguez JDD (2006). Growth and nutritive value of lucerne (Medicago sativa L.) and white melilot (Melilotus albus medik.) under saline conditions. PhD Thesis, School of Agriculture, Food and Wine Discipline of Agricultural and Animal Science, Roseworthy Campus, The University of Adelaide; Australia, p. 84.

Harris Jr B (1997). The importance of fiber in feeding dairy cattle. DS40, The Animal Science, Florida Cooperative Extension Service, Institute of Food and Agricultural Sciences, University of Florida, USA.

Hubbard DI (2016). Essential and non-essential amino acids. Available at www.dwaynehubbard.com [Accessed August 22, 2016].

Kok D, Ates E, Korkutal I and Bahar E (2007). Forage and nutritive value of the pruning residues (leaves plus summer lateral shoots) of four grapevine (Vitis vinifera L.) cultivars at grape harvest and two post-harvest dates. Spanish Journal of Agricultural Research 5: 517-521.

Kostopoulou P, Parissi ZM, Abraham EM, Karatassiou M, Kyriazopoulos AP and Barbayiannis N (2015). Effect of selenium on mineral content and nutritive value of Melilotus officinalis L. Journal of Plant Nutrition 38: 18491861.

Linn $\mathrm{J}$ and Kuehn C (1997). The effects of forage quality on performance and cost of feeding lactating dairy cows. Western Canadian Dairy Seminar 1997 Proceedings, Department of Agricultural, Food \& Nutritional Science 4-10 Agriculture/Forestry Centre University of Alberta Edmonton, AB, Canada.

Luo KL, Jahufer MZZ, Wu F, Di H, Zhang D, Meng X, Zhang J and Wang Y (2016). Genotypic variation in a breeding population of yellow sweet clover (Melilotus officinalis). Frontiers in Plant Science 7: Article 972.

Marković J, Radović J, Lugić Z and Sokolović D (2007). The effect of development stage on chemical composition of alfalfa leaf and stem. Biotechnology in Animal Husbandry 23: 383-388.

Meyer D (2005). Sweetclover: Production and Management. NDSU Extension Service, Fargo, North Dakota, USA.

Milić D, Karagić D, Vasiljević S, Mikić A, Mijić B and Katić S (2011). Leaf and stem chemical composition of divergent alfalfa cultivars. Biotechnology in Animal Husbandry 27: 1505-1511.

NRC (2007). Nutrient requirements of small ruminants: Sheep, Goats, Cervids, and New World Camelids. National Research Council of the National Academies Sciences, the National Academies Press, Washington, D.C.

Ocokoljić S (1975). Leptiraste biljke u ishrani stoke (lucerka, crvena detelina i žuti zvezdan). Nolit, Beograd, p. 251.

Redfearn D, Zhang H and Caddel J (2008). Forage Quality Interpretations. Oklahoma Cooperative Extension Service, Oklahoma State University Division of Agricultural Sciences and Natural Resources, Oklahoma, USA.

Romero JM and Marañón T (1996). Allocation of biomass and mineral elements in Melilotus segetalis (annual sweetclover): effects of $\mathrm{NaCl}$ salinity and plant age. New Phytol. 132: 565-573. 
Tekeli AS, Avcioglu R and Ates E (2003). Changes in some morphological and chemical properties of Persian clover ( $T$. resupinatum $\mathrm{L}$ ) in relation to time and above-ground biomass. Journal of Ankara University Agricultural Sciences 9:352.

Tekeli AS and Ates E (2006). Valores nutritivos de diferentes tréboles anuales (Trifolium sp.) en diferentes etapas de crecimiento. Revista Cubana de Ciencia Agrícola 40: 97-103.

Van Soest PJ, Robertson JB and Lewis BA (1991). Methods for dietary fibre, neutral detergent fibre, and nonstarch polysaccharides in relation to animal nutrition. Journal of Dairy Science 74: 3583-3597.

Veronesi F, Brummer EC and Huyghe C (2010). Alfalfa. In: Broller, B., Posselt, U.K., Veronesi, F. (eds.): Fodder crops and Amenity Grasses. Series: handbook of Plant Breeding, Vol. 5, Springer, New York, USA, pp. 395437.

Yisehak K (2008). Effect of seed proportions of Rhodes grass (Chloris gayana) and white sweet clover (Melilotus alba) at sowing on agronomic characteristics and nutritional quality. Livestock Research for Rural Development 20: 28.

Cite this Article: Ertan Ates (2016). The Effect of Different Growth Stages on Some Forage Quality Characters of the Leaf and Stem in Four Newly Developed Genotypes of Blue Melilot (Melilotus caeruleus (L.) Desr.). Greener Journal of Plant Breeding and Crop Science, 4(5): 087-093, http://doi.org/10.15580/GJPBCS.2016.5.082516139 